\title{
Negotiating Parenting Support: Welfare Politics in Sweden between the 1960s and the 2000s
}

\author{
Sofia Littmarck*, Judith Lind** and Bengt Sandin*** \\ *Department of Thematic Studies - Child Studies, Linköping University, Sweden \\ E-mail: sofia.littmarck@liu.se \\ **Department of Thematic Studies - Child Studies, Linköping University, Sweden \\ E-mail: judith.lind@liu.se \\ ***Department of Thematic Studies - Child Studies, Linköping University, Sweden \\ E-mail: bengt.sandin@liu.se
}

Parent education surfaced as a political question in Sweden in the 1960s and support for parents has since remained on the political agenda. Despite different views on the ideal relationship between the welfare state, the family and children, support for parents has been advocated by parties from all over the political spectrum. By tracing the political debate, this article addresses the question of how the notion of support for parents was adapted to different political ideas, ideologies and ways of defining the relationship between state, family and children from the 1960s until the 2000s in Sweden. We analyse the arguments that different political parties offered and the varying meanings attributed to terms like 'parent education' (föräldrautbildning) and 'parenting support' (föräldrastöd) during three different phases in the transformation of the Swedish welfare state: the final period of its expansion in the 1960s and 1970s; the economic crisis and retrenchments of welfare services in the 1990s; and the era of individual responsibility in the 2000s. Support for parents has been actualised as a solution to different social and political problems and the notions of parent education and parenting support have proven the capacity to accommodate different political ideas, ideologies and visions.

Keywords: Parenting support, parent education, family policy, welfare politics, Sweden.

\section{Introduction}

The hitherto largest investment in support for parents ${ }^{1}$ in Sweden occurred under the governance of the Centre-Liberal-Conservative alliance (the Moderate Party, the Centre Party, the Liberal People's Party and the Christian Democrats) during the period 2006 to 2014. During this period family policy was heavily influenced by the Christian Democrats whose party leader held the position of Minister of Health and Social Affairs. As the Centre and Liberal parties had done since the 1960s in relation to the question of support for parents, the Christian Democrats emphasised the family as an important unit for social policy investments and stressed the necessity of supporting parental responsibility. The Centre-Liberal-Conservative government declared in 2007 that family policy should enable families to lead their lives according to their own desires and needs and should not be forced into 'politically dictated templates' (Lundqvist, 2011: 121). An emphasis on the rights of parents to make choices for their children in various areas came with 
this declaration (Lind, 2012). With the family policy of New Labour in the UK as a model, the Christian Democrats criticised the Swedish welfare state's welfare policies for not being sufficiently family oriented, but focusing on the individual (e.g. Motion 2002/03:So453). Parent education and parenting support whose purpose was changing parental behaviour could have been interpreted as infringing on parental rights and as an invasion of the privacy of the family. Investments in support for parents, however, were portrayed by the Centre-Liberal-Conservative government as provisions that served to empower parents (Socialdepartementet, 2009) and as investments in the family unit (e.g. Motion 2004/05:So395).

Such a view of the family differs considerably from the welfare model associated with the Social Democratic Party (Socialdemokraterna) which was distinguished by an emphasis on universalism and egalitarianism (Esping-Andersen, 1990, 1999). 'Real' individual choice is possible, according to this line of thinking, only if equality has been achieved with the aid of public welfare provisions that free individuals from dependence on their families (Millares, 2015). Rather than the family, it is the individual family members, men, women and children, who are the centre of attention of policies, which has led Berggren and Trägårdh (2015) to refer to this welfare model as state individualism. A provision such as support for parents that builds on acceptance of the child's dependence on its family could be argued to contradict the view of the state as an ally of the individual family member.

Parent education surfaced as a political question in Sweden in the 1960s and support for parents has since remained on the political agenda (cf. Gleichmann, 2004; Lundqvist, 2015; Littmarck, 2017). Despite the fundamentally different views on the ideal relationship between the state, the family, parents and children, support for parents is a policy area that has been advocated by parties over the entire political spectrum from left to conservative. How was this possible? The aim of this article is to address the question of how the notion of support for parents was adapted to different political ideas, ideologies and ways of defining the relationship between state, family and children from the 1960s until the 2000s.

We are doing so by analysing the arguments that different political parties offered in favour of support for parents and the varying content they attributed to terms like 'parent education' (föräldrautbildning) and 'parenting support' (föräldrastöd). By analysing the argumentation, we show how it is possible to understand the fact that support for parents was advocated by parties over the political spectrum - despite the different views on the relationships between the state, family and children. The analysis of the inquiries and the debates identifies the definitions that political agents attributed to support for parents, the problems that parent education and parenting support were argued to remedy, and the political goals that these provisions were supposed to achieve. The analysis focuses on differences regarding how different political parties represented problems and goals. The different and shifting representations of problems and goals are also discussed in relation to changes in political power and general transformations of the welfare state. The analysis displays different lines of argumentation that changed over time and differed between parliamentary parties and agents. As we will show, the arguments through which the support of the different political parties for parent education was expressed varied substantially, as did the political goals that underwrote different conceptions of the relationship between children, parents and the state.

Three different phases in the transformation of the Swedish welfare state help structure the analyses and allow us to discern both consensus and underlying conflicts between 
different parties in Sweden: the final period of expansion of the welfare state in the 1960s and 1970s; the economic crisis and retrenchment of welfare services in the 1990s; and the era of emphasis on individual responsibility in social and family policy in the 2000s.

From an ongoing expansion of welfare services and centralised governance in the 1960s, there was a shift to cuts in public expenditure, retrenchment of welfare services and decentralisation of power due to economic setbacks in the 1990s (e.g. Lundqvist, 2011). The difficulty of suggesting further development of and investments in welfare provisions turned the tables for political debate on the family. The analysis will show how the different political parties advocated support for parents in a political climate marked by economic crisis and transformations of welfare policies.

The source materials include printed reports resulting from government commissions on parent education and parenting support and the parliamentary debates between 1964 and 2009. ${ }^{2}$ Government inquiries have traditionally had a large impact on the political process and government policies. One factor is that the inquiries enabled political negotiation and creation of bipartisan political consensus, often by mobilising current research and expert knowledge (Lundqvist, 2007). The source material from the parliamentary debates primarily consists of bills originating in the parliament, as well as government memoranda and bills. These materials allow an analysis of the potentially different viewpoints of the political parties and agents, and demonstrate different political notions of the relationships between state, family and children. This article focuses on the political argumentation, and it is based on the assumption that institutional politics is mainly text and talk (van Dijk, 1997; Chilton and Schäffner, 2002). In order to understand how political agreements (or disagreements) and choices are made and thus, how different political systems evolve, it is important to analyse the political text and talk and the argumentation - that is, how political agents argue for particular policies, strategies and choices. To understand a political system, we need to understand not only the political outcomes, e.g. laws, reforms or implementations, but also the ideas and notions behind it (Åmark, 2005). In the following sections, we analyse and discuss the political argumentation within the question of support for parents in chronological order, from the 1960s until the late 2000s.

\section{Parent education - a complement to the state-child alliance}

The first proposals to parliament for the introduction of a parent education program came from the Centre Party (Centerpartiet) and the Liberal People's Party (Folkpartiet) in the mid-1960s. They subscribed to the idea of the state's responsibility for children's welfare, but depicted a situation in which the welfare state was not yet sufficiently developed to shoulder this responsibility. For instance, public child care was not yet available for all families (Tallberg Broman, 1995), and one of the problems that was raised in the arguments for parent education was the alleged fact that children were left without proper supervision while their parents were at work (e.g. Motion AK 1968:705; Motion 1972:1105). Another problem description that was used as an argument in support of parent education was the practice of corporal punishment and the psychological maltreatment to which some children were claimed to be subjected. According to this argument, a more stringent ban on corporal punishment was needed than that which was achieved through the revision of the Parental Code in 1966 (Motion FK 1969:492). 
In both cases the centre and liberal proponents of parent education argued that the state could not be relied on for the protection of children against their parents' uninformed judgements. If parents understood the consequences for their children's health and development, the proponents argued, they would see to it that their child was properly tended, despite the lack of public child care (Motion 1972:1105). It was argued that, if parents were given a basic understanding of child psychology, they would not subject children to abuse (e.g. Motion FK 1969:492; Motion FK 1970:188). Hence, the Centre Party and the Liberal Party proposed that, in lieu of state responsibility, the protection of children from parental abuse and maltreatment had to be achieved through changes in parenting practices. Thus, the suggestion implied a strategy based on the protection of children through parents.

\section{Joint ambitions to implement parent education but different political goals}

The Social Democrats did not openly disagree with this conclusion, but they did not explicitly support the idea of parent education either. A plausible interpretation for their lack of commitment to any of the alternatives is that the proposals for parent education at this point did not constitute obstacles to further investments in welfare provisions directed to the child, such as child care. A few years into the 1970s the Social Democratic welfare model was more firmly established. Almost immediately, however, it was subjected to critique. It was costly - and, despite the substantial rise in the general standard of living and increase in welfare provisions for children, children's living conditions and their situation within the family were claimed by MPs of all political parties not to have improved accordingly. Despite better living standards for the family there was a general agreement that problems related to children's living conditions had not yet been solved by the welfare state. All parliamentary parties now became engaged in the debate about parent education with the aim of putting their perspectives into its formation (e.g. Motion 1973:2048; Motion 1974:442; Motion 1975/76:1272). In 1973 the Social Democratic government appointed a bipartisan parliamentary inquiry, and in 1979 a decision was reached that paved the way for the implementation of general parent education (Proposition 1978/79:168; Socialutskottet 1978/79:45; Skrivelse 1978/79:385). However, the Centre Party, the Liberal People's Party, the Social Democrats, the Left Party (Vänsterpartiet Kommunisterna), and, later, the public inquiry that was appointed by the Social Democratic government (Barnomsorgsgruppen), all had different approaches to the implementation of parent education.

According to the public inquiry and the Centre MPs, the problem was that the education system, despite the reforms of the previous decade, was unable to 'compensate for early incurred educational and social disabilities and to prevent the emergence of new class differences in society' (Motion 1973:2041:1). According to this line of argument, the reason was that children were formed by the social environments of their families in the early years of their lives (e.g. Motion 1973:1309; Motion 1973:2041; SOU 1978:5). Once they started school, or even preschool, their development and life chances were already influenced by their parents' ability to stimulate their children's intellectual, social and emotional development. Consequently, the only way for the state to influence children's development in the early years of childhood, and thereby their future life chances, was by influencing the parents. Through parent education, parents should be equipped for their responsibility for their child's welfare, a development within the family unit. 
The political parties did, however, have different approaches to the development of the welfare state's capacities. Whereas the Centre Party argued that the educational system alone could not level the inequality in children's life chances, the Left Party and the inquiry appointed by the Social Democrats claimed instead that the problem was that the welfare system and communal responsibility for children were not yet sufficiently developed (e.g. Motion 1977/78:1111; SOU 1980:27). MPs of the Left Party and the public inquiry agreed that children's living conditions had not (yet) developed in the right direction, but claimed that the problem was the social isolation of the nuclear family and the lack of collective responsibility for children. Furthermore, their isolation made parents vulnerable to influence from the commercial market and its images of parenthood and family life (Motion 1977/78:1111; SOU 1978:5; SOU 1980:27). Parent education, its proponents on the far left argued, could offer a realistic image of parenthood and counter the glorified and commercial image of nuclear family life (e.g. Motion 1977/78:1111). Furthermore, parent education should also prepare parents for the task of actively trying to change society. In the left's vision of the welfare state (including the Social Democrats) parent education was assigned the role of changing not merely the manner in which children were parented, but also how the parents viewed parenthood and the role of children and the family in society at large (Motion 1976/77:1108; Motion 1978/79:2482; SOU 1980:27; cf. Gleichmann, 2004). Parents were also found to be sceptical of the idea of being educated (SOU 1980:27). The public inquiry argued that parent education should not primarily educate parents in a traditional sense but 'encourage parents to work together for social change, so that we can achieve a society that, to a higher degree, is planned to accommodate the needs of children' (SOU 1978:5:11; SOU 1980:27:46). In order to achieve this, the inquiry argued, parents had to be encouraged to become more involved with their children's school and to exercise their democratic rights by trying to influence decisions at the local level (SOU 1978:5; SOU 1980:27). In this manner the inquiry as well as the political left argued for a communal responsibility for children's living conditions shared by parents, the public and the welfare state institutions.

The arguments for parent education thus originated from a joint critique of the welfare state and the provisions for families and children that were put in place in order to achieve improvements in children's living conditions and social equality. All parties agreed on the idea of parent education, although the Centre and Liberal politicians argued for enabling parent responsibility within the family, and the political left wanted to increase communal responsibility for children among the family, the public and the state. Hence, the Left did not necessarily view parent education as a means to strengthen the role of the family. Furthermore, by now many of the welfare reforms that were the goal of the Social Democrats (e.g. a universal child benefit program, public child care, paid parental leave, and a comprehensive educational system) had been achieved.

\section{Parenting support - compensating the welfare state crisis and strengthening the capacities of parents}

The economic crisis in the 1990s contributed to a new context for the debate about parent education. High unemployment rates affected families, particularly those who were already socially vulnerable (Bergmark and Palme, 2003). The Social Democratic government was followed in 1991 by a coalition led by the conservative Moderate Party 
(Moderata samlingspartiet) and supported by the Centre Party, the Liberal People's Party and the Christian Democrats (Kristdemokraterna), which, in turn, in 1994 again lost power to the Social Democrats. Decisions about cutbacks in public funding for education, child care and child allowances, and the reduction of the role of the central government were made by both governments. The cutbacks coincided with a shift to a neoliberal rhetoric. It was used to provide ideological legitimacy for the cutbacks by emphasising freedom of choice and the introduction of private, market-based alternatives (Lundqvist, 2011).

In the mid-1990s the Social Democratic government initiated a new public inquiry about parent education after initiatives from all political parties, but especially from the Centre Party and the Christian Democrats. In 1997 the inquiry, which was led by a Social Democrat, concluded that the economic crisis and retrenchments of welfare services had caused the re-emergence of social inequality and decreased child wellbeing within the family (SOU 1997:161). In contrast to the 1978 and 1980 inquiries and despite specific references to societal factors as the causes of challenges to the family, the inquiry's argument for parent education did not contain any visions for political change. What was stressed instead by the Social Democratic Ministry of Health and Social Affairs (Socialdepartementet, 1996) was that it was the parents who had the primary responsibility for their children's welfare. So, parallel with the welfare state taking a step back, parents were expected to take a step forward, to acknowledge their importance and to believe in their capacity in parenting. Parents could not, however, be left alone with this responsibility. The role that they played was regarded as far too decisive for their children's lives and futures. For parents to be able to shoulder greater responsibility for their children's welfare it was claimed that they needed support (SOU 1997:161. cf. Gleichmann, 2004; Wissö, 2012; Sandin, 2013; Lundqvist, 2015).

At the same time, the entire idea of educating parents about how they should care for and rear their children was now seen as problematical. It did not fit well with the general scepticism of a patronising welfare state (Berggren and Trägårdh, 2015), nor did it fit well with the image of parents as capable of assuming the primary responsibility for their children's welfare. In the 1997 inquiry the term 'parent education' was perceived as paternalistic and as giving the wrong impression about the intervention (SOU 1997:161). MPs advocating investments in support for parents balanced between attributing problems to families by making the investment necessary on the one hand, and portraying parents as capable of assuming responsibility for their child's well-being on the other (e.g. Motion 1996/97:So636; Motion 1996/97:So638).

The new preferred term was parenting support (föräldrastöd) or support in parenthood (stöd i föräldraskapet). It was suggested by the public inquiry as a new umbrella term for a wide range of support measures offered to parents with children in all age groups and, in addition to support groups for parents, included 'well-functioning preschools, schools and after school centres' (SOU 1997:161:111). For the Social Democrats the emphasis on parental responsibility constituted a new way of arguing in relation to matters that concerned child welfare. The inquiry's proposal regarding parent education was, however, half-hearted. A broad definition of parenting support was given by the inquiry, but the lack of a national policy and budget reforms, and the reliance on local initiatives meant that the inquiry's proposals did not imply any radical changes within the question of support for parents. 


\section{Parenting support - emphasising the value of the family and the parent-child relationship}

In the early 2000s some of the welfare provisions that were reduced during the previous decade were restored, such as the parental leave scheme and child benefits (Hiilamo, 2004). This did not, however, lead to a decreased interest in parents and parenting support. The Social Democratic government acknowledged the importance of preventive investments in the family in the form of parenting support to complement other welfare measures, not least to prevent later costs for the treatment of mental health disorders in children and social exclusion (e.g. Skrivelse 2001/02:166). A new inquiry was initiated in the early 2000s that focused on new and effective ways of supporting parents (Bremberg, 2004), but it was the coalition government of the Moderate Party, the Centre Party, the Liberal People's Party and the Christian Democrats, which governed Sweden between 2006 and 2014, that provided the foundation for a national strategy for parenting support (Socialdepartementet, 2009). The political landscape during this time period was in part characterised by the Moderate Party's ambition to reinvent itself, which entailed an explicit acceptance of the state's responsibility for improving and equalising children's living conditions, a stance that was new for the party (see, e.g. Moderaterna, 2012). In the Moderate Party there was also a new emphasis on welfare investments in children in order to achieve equality in the children's life chances. Despite being the smallest of the coalition parties, the rhetoric of the Christian Democrats also came to play a significant role not only in the continuing political debate about parenting support. As responsible for the Ministry of Health and Social Affairs they also set the public agenda in questions regarding family policy in general.

The welfare provisions restored after the previous decade were paralleled by a strong focus on the family unit. When the Centre Party, the Liberal People's Party and the Christian Democrats argued in favour of a developed parenting support, they did so by pointing to the problem constituted by a deterioration of the mental health state of children and youth. The cause of children's declining mental health was claimed to be the relations within the family. The exclusivity of the parent-child relationship was put forward even more explicitly during this period (e.g. Proposition 2007/08:110. cf. Lundqvist, 2015). According to the rhetoric of the Centre-Liberal-Conservative government, 'to promote children's health and welfare, it is necessary to support the parents' (Proposition 2006/07:129:43). Notions of the importance of the parent-child relationship fit well with the political standpoints of the Christian Democrats and their ambition to promote the family unit.

Parenting support was now addressed as a way not only to reduce costs, but also as an investment with potential profits, both economic and human. Moreover, parents, the inquiry argued, now asked for advice on parenthood (SOU 2008:131). Social Democratic MPs did however criticise the Centre-Liberal-Conservative government for focusing too little on investments aimed directly at children suffering from mental ill health (Motion 2007/08:So20), but welcomed overall the investments in parenting support.

The different positions that were carved out during this period could be accommodated to the traditional Social Democratic way of organising welfare in Sweden, but the content deviated with its emphasis on support of the family. In the national strategy for parent support launched in 2009 the Centre-Liberal-Conservative government followed the Social Democratic tradition of universal provisions of welfare services (Sandin, 2011; 
Sandin and Bergnéhr, 2013). Parenting support should, according to the strategy, be offered to all parents, and it should not stigmatise or single out specific groups with special needs, as, for example, newly arrived immigrant groups (SOU 2008:131; Socialdepartementet, 2009). However, the focus was now on parent's ability to recognise children's needs and healthy family interaction. The proposals of the Centre-Liberal-Conservative government were not introduced as an alternative to other welfare provisions, but rather as a part of the restoration of welfare services that had been in decline since the 1990s.

\section{Conclusions}

Despite the different views on the ideal relationship between the state, the family, parents and children, support for parents has been advocated by those ranging from the political left to the conservatives. The analysis of the inquiries and parliamentary debate on support for parents during this period shows that different political parties advocated the idea of support for parents to achieve different political goals. Parenting support has been adapted to different ideas about how the relationships between children, family and the state ought to be organised, including the welfare society.

In the 1960s and 1970s the debate focused on maltreatment, abuse and children's living conditions in the welfare state. These conditions included the social environment in the home and family, which was thought to form children's health and life chances. Parent education was viewed as a way to deal with the limitations of the welfare state in its role of complementing and compensating for problems that were attributed to parents and family situations. Whereas Centre and Liberal politicians saw the state's limitations as consequences of the necessity of enhanced parental responsibility, the left saw these limitations as results of a welfare system not yet fully developed. Furthermore, the Centre and Liberal politicians viewed parent education as a means of changing parents and their behaviour towards their children, while the government inquiry and the left argued for parent education to enhance the political awareness of parents by involving them in the process of changing society. This implied stimulating an increased communal responsibility for children. The general agreement on the importance of parent education during this period thus relied on very different views on the relationship between parents, children and the welfare state, as well as on the specific aims of parent education. It was perceived both as a solution to achieve increased communal responsibility for children and as a way to enhance parents' capacities to take responsibility for children's development and health within the family unit.

During the economic recession of the 1990s the Social Democrats accepted the increase in responsibility of parents as a natural effect of an ideology that emphasised individual choice and self-determination. The increased reliance on parents was paralleled by an increased focus on the parent-child relationship. However, with the introduction of a new umbrella concept, support in parenthood or parenting support, a broadening of the investment occurred. The 1997 public inquiry led by the Social Democrats included preschools and after school centres in the definition of support in parenthood which dissolved the distinction between parenting support and other welfare provisions for children and families. Thus, the proposals presented by the public inquiry at the time adhered to the demands of new investments in parents, although also emphasising welfare investments directed directly to children. 
The national strategy of parenting support in Sweden that was in place from 2009 was primarily the product of the political coalition between the Moderate Party, the Centre Party, the Liberal People's Party and the Christian Democrats that held the mandate to govern between 2006 and 2014. The Centre-Liberal-Conservative government, however, suggested a universalistic approach, which had parenting support programs aimed at all parents and which rejected targeted plans. The government thus became aligned with decades of Swedish general welfare reforms put forward by the Social Democrats. The focus of the Centre-Liberal-Conservative government on parenting support was not presented as an alternative to other welfare provisions in the political debate, but rather was paralleled by a restoration of welfare services for children and families that had seen cuts during the economic crisis in the 1990s.

Support for parents has been actualised as a solution to different social and political problems in a welfare society going through significant transformations between the 1960s and late 2000s. The notion of parent education and parenting support has proven the capacity to accommodate different political ideas and ideologies and ways of defining the relationship between state, family and children. At the same time, we have been able to show that this accommodation to changing political regimes and the consensual political process indeed hide important differences and political visions of the nature of the welfare society.

\section{Notes}

1 We use the term support for parents as a unifying concept for the different terms that were used in the Swedish political debate. Parent education (föräldrautbildning) was the term used from the 1960s to the 1990s, when it was replaced by the umbrella concept support in parenthood (stöd i föräldraskapet) and parenting support (föräldrastöd).

2 The analysis in this article is based on the data collection and processing performed by Littmarck for her dissertation about the political debate about parent education and parenting support (Littmarck, 2017).

\section{References}

Åmark, K. (2005) Hundra år av välfärdspolitik: välfärdsstatens framväxt i Norge och Sverige [One hundred years of welfare politics: the growth of the welfare state in Norway and Sweden], First edtition Umeå: Boréa.

Berggren, H. and Trägårdh, L. (2015) Är svensken människa? Gemenskap och oberoende i det moderna Sverige [ls the Swede Human: Autonomy and Community in Modern Sweden], Stockholm: Norstedts.

Bergmark, A. and Palme, J. (2003) 'Welfare and the unemployment crisis: Sweden in the 1990s', International Social Welfare, 12, 108-22.

Bremberg, S., ed. (2004) Nya verktyg för föräldrar: förslag till nya former av föräldrastöd [New tools for parents: proposals for new forms of parenting support], Stockholm: Statens folkhälsoinstitut.

Chilton, P. and Schäffner, C. (2002) 'Introduction: themes and principles in the analysis of political discourse', in P. Chilton and C. Schäffner (eds.), Politics as Text and Talk, Amsterdam: John Benjamin's Publishing Company, 1-41.

Esping-Andersen, G. (1990) The Three Worlds of Welfare Capitalism, Cambridge: Polity Press.

Esping-Andersen, G. (1999) Social Foundations of Post-Industrial Economies, Oxford: Oxford University Press. 
Gleichmann, L. (2004) Föräldraskap mellan styrning och samhällsomvandling. En studie av syn på föräldrar och relationen mellan familj och samhälle under perioden 1957 - 1997 [Parenthood between control and society's transformation. A study of the view on parents and the relation between family and society during the period 1957-1997], Stockholm: HLS Förlag.

Hiilamo, H. (2004) 'Changing family policy in Sweden and Finland during the 1990s', Social Policy and Administration 38, 1, 21-40.

Lind, J. (2012) 'Föräldrainflytande och barnets bästa' [Parental influence and what is best for the child], in K. Engwall and S. Larsson (eds.), Utanförskapets historia. Om funktionsnedsättning och funktionshinder [The history of marginality: On disablement and disability], Stockholm: Studentlitteratur, 99-112.

Littmarck, S. (2017) Barn, föräldrar, välfärdsstat: Den politiska debatten om föräldrautbildning och föräldrastöd 1964-2009 [Children, parents, welfare state. The political debate about parent education and parenting support 1964-2009], Linköping: Linköpings universitet.

Lundqvist, Å. (2007) Familjen i den svenska modellen [The family in the Swedish model], Umeå: Boréa.

Lundqvist, Å. (2011) Family Policy Paradoxes. Gender Equality and Labour Market Regulation in Sweden, 1930 - 2010, Bristol: Polity Press.

Lundqvist, А. (2015) 'Parenting support in Sweden: new policies in old settings', Social Policy and Society, 14, 657-68.

Millares, M. (2015) Att välja välfärd. Politiska berättelser om valfrihet [Choosing welfare. Freedom of choice and Political Ideology in Sweden] (diss.), Stockholm: Stockholms universitet.

Moderaterna (2012) Välfärdspolitik som förbättrar barns uppväxtvillkor [Welfare policies that improve children's living conditions], http://www.moderat.se/sites/default/files/attachments/barngruppen_-_lika_ mojligheter_for_alla_barn_-_slutversio.pdf [accessed 01.02.2017].

Motion AK 1968: 705, I. Frænkel, M. P. Hamrin, A. Jonsson and E. Jönsson (fp), Angående föräldrautbildning och familjerådgivning, Swedish Parliament.

Motion FK 1969: 492, E. Olsson, M. Pehrsson, N.-E. Gustafsson and J. A. Olsson (cp), Angående föräldrautbildningen, Swedish Parliament.

Motion FK 1970: 188, E. Olsson (cp) and R. Hamrin-Thorell (fp), Om försöksverksamhet med föräldrautbildning, Swedish Parliament.

Motion 1972: 1105, G. Helén (fp) and T. Fälldin (c), En effektivare föräldrautbildning, Swedish Parliament.

Motion 1973: 1309, B. Olsson and B. Stålhammar (fp) Om obligatorisk föräldrautbildning, http://riksdagen.se/sv/dokument-lagar/dokument/motion/om-obligatorisk-foraldrautbildning_ FW021309 [accessed 11.12.2017].

Motion 1973: 2041, T. Fälldin, J. Antonsson, B. Jonasson, E. Olsson, F. Börjesson, T. Bengtson, L. Mattsson, K. Söder, R. Dockered, R. Gustavsson, A.-L. Nilsson and J.-I. Nilsson (c), I anledning av Kungl. Maj:ts proposition 1973:136 om förskoleverksamhetens utbyggnad och organisation, http://riksdagen.se/sv/dokument-lagar/dokument/motion/i-anledning-av-kungl-majts-proposition1973136_FW022041 [accessed 11.12.2017].

Motion 1973: 2048, E. Svensson, T. Jadestig, K.-G. Andersson, B. Zachrisson, L. Henrikson, G. Gustafsson and B. Rosqvist (s), I anledning av Kungl. Maj:ts proposition 1973:136 om förskoleverksamhetens utbyggnad och organisation, http://riksdagen.se/sv/dokument-lagar/dokument/motion/i-anledning-avkungl-majts-proposition-1973136_FW022048 [accessed 11.12.2017].

Motion 1974: 442, M. Werner, I. Sundberg, T. Nilsson, R. Clarkson, W. Komstedt (m), Om en utredning rörande föräldrautbildning, http://riksdagen.se/sv/dokument-lagar/dokument/motion/om-enutredning-rorande-foraldrautbildning_FX02442 [accessed 11.12.2017].

Motion 1975/76:1272, I. Lantz, P. Israelsson, A. Lövenborg and J. Magnusson (vpk), Om en allmän föräldrautbildning, http://riksdagen.se/sv/dokument-lagar/dokument/motion/om-en-allmanforaldrautbildning_FZ021272 [accessed 11.12.2017].

Motion 1976/77:1108, I. Lantz, N. Berndtson, J. Svensson, T. Claeson and T. Franzén (vpk), Om föräldrautbildning, http://riksdagen.se/sv/dokument-lagar/dokument/motion/om-foraldrautbildning G0021108 [accessed 11.12.2017]. 
Motion 1977/78:1111, L. Werner, E. Marklund, N. Berndtson, I. Lantz, C.-H. Hermansson and J. Svensson (vpk), Av föräldrautbildning, http://riksdagen.se/sv/dokument-lagar/dokument/motion/ av-foraldrautbildning_G1021111 [accessed 11.12.2017].

Motion 1978/79:2482, S. Aspling, D. Håvik, L. Öhrsvik and A.-G. Skantz (s), Med anledning av propositionen 1978/79:168 om föräldrautbildning och förbättringar av föräldraförsäkringen m. $\quad$ m., http://riksdagen.se/sv/dokument-lagar/dokument/motion/med-anledning-av-propositionen197879168-om_G2022482 [accessed 11.12.2017].

Motion 1996/97:So636, A. Svensson (kd), Familjepolitiken, http://riksdagen.se/sv/dokument-lagar/ dokument/motion/familjepolitiken_GK02So636 [accessed 11.12.2017].

Motion 1996/97:So638, I. Irhammar (c), Social trygghet, http://riksdagen.se/sv/dokument-lagar/dokument/ motion/social-trygghet_GK02So638 [accessed 11.12.2017].

Motion 2002/03:So453, M. Oscarsson (kd), Stöd till familjen, http://riksdagen.se/sv/dokument-lagar/ dokument/motion/stod-till-familjen_GQ02So453 [accessed 11.12.2017].

Motion 2004/05:So395, B. Carlsson, K. Johansson, B. Sellén, S. Larsen, J. Andersson, M. Andersson and A. Qarlsson (c), Bättre barndom, http://riksdagen.se/sv/dokument-lagar/dokument/motion/ battre-barndom_GS02So395 [accessed 11.12.2017].

Motion 2007/08:So20, Y. Johansson, C. Engelhardt, L. U. Granberg, M. Pettersson, L. Axelsson, C. Bråkenhielm, P. Svedberg and A. Arleklo (s), Med anledning av prop. 2007/08:110 En förnyad folkhälsopolitik, http://riksdagen.se/sv/dokument-lagar/dokument/motion/medanledning-av-prop-200708110-en-fornyad_GV02So20 [accessed 11.12.2017].

Proposition (Proposition/Bill) 1978/79:168 Om föräldrautbildning och förbättringar av föräldraförsäkringen $\quad m . \quad m . \quad$ http://riksdagen.se/sv/dokument-lagar/dokument/proposition/omforaldrautbildning-och-forbattringar-av_G203168 [accessed 11.12.2017].

Proposition 2006/07:129 Utveckling av den sociala barn- och ungdomsvården m.m. http://riksdagen.se/sv/dokument-lagar/dokument/proposition/utveckling-av-den-sociala-barn-ochungdomsvarden_GU03129 [accessed 11.12.2017].

Proposition 2007/08:110 En förnyad folkhä/sopolitik, http://riksdagen.se/sv/dokument-lagar/dokument/ proposition/en-fornyad-folkhalsopolitik_GV03110 [accessed 11.12.2017].

Sandin, B. (2011) 'Föräldraskap - ett konstant samhällsproblem' [Parenthood - a constant social problem], Locus, 2, 58-76.

Sandin, B. (2013) 'The history of children's well-being in the West', in A. Ben-Arieh, F. Casas, I. Frones and J. E. Korbin (eds.), Handbook of Child Well-Being. Theories, Methods and Policies in Global Perspective, Dorcrecht: Springer, 31-86.

Sandin, B. and Bergnéhr, D. (2013) Samverkande föräldrastöd - nätverk för forskning och utveckling [Cooperative parenting support - a network for research and development], Research on Childhood and the Study of Children, 2, Linköping: Linköping University Electronic Press.

Skrivelse (Memoranda) 1978/79:385 Till regeringen, Socialdepartementet, Swedish Parliamnet.

Skrivelse 2001/02:166 Barnpolitiken - arbetet med strategin för att förverkliga FN:S konvention om barnets rättigheter, http://riksdagen.se/sv/dokument-lagar/dokument/skrivelse/ barnpolitiken_arbetet-med-strategin-for-att_GP03166

Socialdepartementet (Ministry of Health and Social Affairs) (2009) Nationell strategi för ett utvecklat föräldrastöd. En vinst för alla, Stockholm: Socialdepartementet.

Socialdepartementet (1996) Bilaga till regeringens protokoll 1996-02-22 in Ds 1997:6 Stöd i föräldraskapet, Stockholm: Socialdepartementet.

Socialutskottet (SoU) (The Social Committee) 1978/79:45, Med anledning av propositionen 1978/79:168 om föräldrautbildning och förbättringar av föräldraförsäkringen m.m. såvitt avser förslag om föräldrautbildning jämte motioner, http://riksdagen.se/sv/dokument-lagar/arende/ betankande/med-anledning-av-propositionen-197879168-om_G201SoU45 [accessed 11.12.2017].

SOU 1978: 5 Föräldrautbildning 1. Kring barnets födelse, Stockholm: Socialdepartementet.

SOU 1980: 27 Barn och vuxna, Stockholm: Socialdepartementet.

SOU 1997: 161 Stöd i föräldraskapet, Stockholm: Socialdepartementet. 
SOU 2008: 131 Föräldrastöd - en vinst för alla. Nationell strategiför samhällets stöd och hjälp till föräldrar i deras föräldraskap, Stockholm: Socialdepartementet.

Tallberg Broman, I. (1995) Perspektiv på förskolans historia [Perspectives on pre-school history], Lund: Studentlitteratur.

van Dijk, T. A. (1997) 'What is political discourse analysis?', Belgian Journal of Linguistics, 11, 1, 11-52.

Wissö, T. (2012) Småbarnsföräldrars vardagsliv: Omsorg, moral och socialt kapital [The everyday life of parents of small children: Care, morality and social capital], Göteborg: Göteborgs universitet. 